\title{
PRIMARY CARE AS A MEANS OF DECREASING HEALTH CARE COSTS
}

\section{Mrs Martie M van Deventer (neè Seymore)}

MCur student, Department of Health Studies, University of South Africa

Head: Medical Department, CSIR, Pretoria

\section{Dr Susan P Hattingh}

BCur (I et A), M Cur, D Litt et Phil

Senior Lecturer, Department of Health Studies, University of South Africa

\section{Dr Marthie C Bezuidenhout}

BCur (I et A), M Cur, D Litt et Phil

Senior Lecturer, Department of Health Studies, University of South Africa

Corresponding author: bezuimc@unisa.ac.za

Key phrases: Primary health care; primary care; managed health care; medical scheme; cardiovascular disease, early detection

\section{ABSTRACT}

The study was focussed at furthering the health objectives of the Government's Reconstruction and Development Programme in the area of primary care. The purpose of the study was to examine the possible reduction of medical scheme claims for cardiovascular disease by means of primary care, so that medical scheme benefits do not become exhausted so rapidly. A quantitative approach, using an explorative and descriptive design was used. A survey was done by means of a questionnaire which was distributed to 250 principle members of the medical scheme in four selected divisions of a private organisation. Thereafter, a limited clinical assessment was done on the participants. In addition, case studies were used to illustrate the cost savings that could be obtained by the delivery of managed primary care of cardiovascular (CVD) conditions. Twenty-seven percent of the participants had current, or a history of cardio-related conditions, and 32.15 percent of the participants were identified as having an overall high risk for CVD. Contributing circumstances aggravating these conditions were lifestyle-related issues. Nurse-based primary care should focus on primary prevention, for example, taking personal responsibility, weight management, sufficient exercise, discontinuing smoking habits, stress management, and secondary prevention which involves annual medicals, and a focussed approach of specific screening protocols.

\section{OPSOMMING}

Die studie was gemik op die bevordering van die gesondheidsdoelwitte van die regering se Herkonstruksie en Ontwikkelingsprogram ("Reconstruction and Development Programme") op die gebied van primêre sorg. Die doel van die studie was om die moontlike vermindering van mediese skema-eise met betrekking to kardiovaskulêre siektes, deur middel van primêre sorg te ondersoek sodat mediese skema-voordele nie so gou uitgeput raak nie. ' $n$ Kwantitatiewe benadering met behulp van 'n ondersoekende en beskrywende ontwerp is benut. ' $n$ Opname is deur middel van ' $n$ vraelys gedoen wat aan 250 primêre lede van die betrokke mediese skema in vier geselekteerde afdelings van die privaat maatskappy versprei is. Beperkte kliniese evaluering is daarna op die deelnemers gedoen. Gevallestudies is ook gebruik om die kostebesparings te illustreer wat met behulp van die lewering van bestuurde primêre sorg van kardiovaskulêre siektes bewerkstellig kan word. Sewe-en-twintig persent van die deelnemers het 'n geskiedenis van, of huidige tekens van kardiovaskulêre siektes getoon, terwyl 32.15 persent van die deelnemers as persone met ' $n$ hoë risiko vir kardiovaskulêre siektes geïdentifiseer is. Bydraende toestande, soos leefstylfaktore, het tot verswaring van die toestande gelei. Verpleeg-gebaseerde primêre sorg behoort op primêre voorkoming deur middel van die neem van persoonlike verantwoordelikheid, gewigsbeheer, voldoende oefening, die staking van 
rookgewoontes en spanningsbestuur te fokus, asook op sekondêre voorkoming, wat jaarlikse mediese ondersoeke en 'n gefokusde benadering tot spesifieke siftingsprotokolle, insluit.

\section{INTRODUCTION}

The study was focused at furthering the health objectives of the Government's Reconstruction and Development Programme in the area of primary care. The purpose of the study was to examine the possible reduction of medical scheme claims for cardiovascular disease by means of nurse-based managed primary health care, so that medical scheme benefits do not become exhausted so rapidly. This project was done by means of a quantitative approach, utilising three different methods of data collection.

\section{SYNOPSIS OF THE CURRENT HEALTH CARE SYSTEM}

Government policy regarding health care in South Africa stipulates that individual medical care and wellbeing are the personal responsibility of individuals. The State does, however, accept responsibility for people who are unable to afford medical coverage. This policy has given rise to a two-tier system in the provision and financing of health care, namely the public and the private health sectors.

The State plays a dominant role in the provision and financing of both curative and preventive health facilities and health services at regional and community levels.

The financing of health care in the private sector has predominantly come from medical schemes, which are, by law, nonprofit organisations whose main aim is to assist members with their medical expenses. Private health care professionals and private hospitals provide health care in this sector (Ernst \& Young Management Services, 1993:16).

\section{ESCALATING HEALTH CARE COSTS IN SOUTH AFRICA}

The main factors contributing towards the escalating health care costs in South Africa include an increase in the sophistication of medical technology, ageing of the medical scheme population, general inflation in all products and services, an increase in the number of providers of health services, the emergence of new diseases such as acquired immunodeficiency syndrome (AIDS), unhealthy lifestyles, environmental pollution, and little or inappropriate health planning (Ernst \& Young Management Services, 1993:31).

Currently a large proportion of medically insured patients in South Africa use health services on a fee-forservice basis. The patient may or may not negotiate a discount for services rendered, for example, regarding the medication. If the medication proves to be expensive, the patient is not concerned because the patient assumes that the "medical scheme pays for it". Patients frequently have no idea of the cost of the medication, nor do the concepts "generic" and "therapeutic" substitution mean anything to them (Gore, 1993:7). Thus, the member's medical scheme benefits could rapidly become exhausted. The costs of health care are becoming increasingly disproportionate to the funds available to pay for them.

\section{APPLICATION OF PRIMARY HEALTH CARE (PHC) IN THE PRIVATE SECTOR}

Dennill, King and Swanepoel (1999:2) stated that PHC is the first level of contact of individuals, the family and community with a national health system, bringing health care as close as possible to where people live and work, and constitutes the first element of a continuing health care process (WHO, 1988:32). PHC aims at quality care, which is accessible to those who need it. Resources are being shifted into primary care, health promotion, diagnosis and prevention, rather than being funneled almost exclusively into the treatment of disease, as was the case in the past.

The direction that health care took in the 1980s was given statutory backing by the National Policy for Health Act 116 of 1990 . It emphasised the following four principles:

- Individuals should take responsibility for their own and their families' physical, mental and social wellbeing.

- Costs incurred by individuals for health care should 
be recovered from them, but the indigent must be accommodated by the State.

- The private sector should be encouraged to provide health services that are in the interests of the public.

- State and local authorities should provide a comprehensive health service that takes into consideration all available resources (Dennill et al. 1999:35).

Increasingly, the health system continues to move away from the institutionally-based care provided by hospitals to more front line primary and preventative care throughout the community where it is delivered by a wider choice of providers, such as nurse practitioners (Kreider, 1999:65). To ensure that PHC is of a high quality it needs to be carried out in a managed health care context.

\section{APPLICATION OF MANAGED HEALTH CARE PRINCIPLES}

Kongstvedt (1993:505) describes managed care as a system of health care that aims to provide quality care which is accessible to those who need it. Managed care is based on the belief that a health care system should work to keep people healthy and when they are sick or injured, should work to assure the right treatment in the right setting by the right person. It should prevent, as well as manage, diseases and illnesses. According to Ceslowitz (1993:366) it aims at cost-efficiency without compromising quality of care. If anything, it aims at value for money.

The following managed health care principles need to be applied in addressing the excessive medical scheme claims:

- Health promotion, prevention, early diagnosis and treatment delivered preferably by a primary health care nurse.

- Networking between preferred providers, identified as the general practitioner, qualified nurses, the dietician, the physiotherapist, specialists and the pharmacist, who should collaborate with the medical scheme.

- Price negotiation: that doctors and other health care providers charge the Board of Healthcare Funders' (BHF) tariffs and not contracted-out fees (Ceslowitz, 1993:366).

\section{MEDICAL SCHEMES}

The De Beers Mining Company started the first medical scheme in 1889 for its employees (Ernst \& Young Management Services, 1993:16). Since then there has been a proliferation of medical schemes in South Africa and in 1967 the Medical Schemes Act (South Africa 1967) was introduced to control the structure and functioning of these schemes.

The Board of Healthcare Funders (BHF) is a statutory body formed in terms of the Medical Schemes Act 131 of 1998 (South Africa 1998), to represent the interests of medical schemes. It is also responsible for publishing the Scale of Benefits in the Government Gazette.

Medical schemes are a form of health insurance, which pays for the services received by members and their dependants from health care practitioners of their choice. The scheme pays for the cost of medical care for the member (and specified dependants) within the limits of a specific package of benefits. Providers are paid on a fee-for-service basis, thus medical schemes effectively guarantee payment to health care providers if they charge according to the Scale of Benefits.

Employers usually establish medical schemes, or negotiate medical insurance on behalf of their employees with individual schemes, and require their employees to join these schemes. Employers normally contribute a percentage of the monthly fee as a service benefit.

The medical scheme's only income is the contributions received from members (and employers). The trustees must manage the scheme within the constitution of this medical scheme and by means of these contributions, to ensure the scheme's continued sustainability.

According to statistics provided (Van Emmenis, 2000), the specific medical scheme under study consists of 3000 members. These members claimed a total of more than R33 million (R33 557 565.36) during 1999 for medical care.

\section{RATIONALE FOR THE STUDY}

This study was conducted at a PHC clinic, situated on the premises of a private company in Gauteng. The company has its own medical scheme with an inde- 
pendent administrator.

Medical scheme benefits are calculated and administered within the time frame of a calendar year. According to the available information, for this company, 20 percent of the medical scheme members had already utilised their full medical aid benefits, while another 20 percent had spent more than their day-to-day allowances for the current year before June of the specific year (2000). Thus, their funds were exhausted. It is therefore of the utmost importance to reduce the number of medical scheme claims to keep affordable health care within the reach of the employees of this company.

According to statistics for the three preceding years (Van Emmenis, 2000), the most common health problems are cardiovascular (CVD) related conditions. For this reason the researcher focused on the provision of managed primary care to reduce the medical scheme claims for CVD.

\section{CARDIOVASCULAR DISEASE (CVD)}

In 1998, the WHO (1998:4) stated that up to 50 percent of mortality in developed countries is caused by CVD. By the year 2000, it is expected that this group of diseases would be responsible for a quarter of the deaths in the Third World countries. CVD remains the most important cause of early invalidity, professional inactivity and premature death.

\section{Defining CVD}

According to German and Hoffman-La Roche (1996:27), CVD is a collective term for diseases related to problems affecting the heart and the blood circulation. In the broadest sense, CVD means disorders of the blood vessels which ultimately impair blood supply to both the heart (cardiovascular) and the brain (cerebro-vascular).

\section{Aetiology of CVD}

According to German and Hoffman-La Roche (1996:30), the causes of CVD as a degenerative group of diseases are multiple. A lesion and subsequent obstruction of the blood vessel (plaque) is a major underlying condition and is referred to as atherosclerosis.
Plaque consists of a conglomeration of lipids, cholesterol and cells deposited on the inside of arteries. Such deposits may build up over a lifetime, to the point where the flow of blood is impaired or completely blocked. As the heart struggles to get by with a diminished oxygen supply, a typical chest pain or angina pectoris occurs (German \& Hoffman-La Roche, 1996:30).

The narrowed passage for blood transport is vulnerable to blocking by a blood clot (thrombosis), which would cut off the flow of blood completely. When biological tissue is cut off from its regular blood supply by an obstruction, the resulting situation is called ischemia. This causes a stroke if it occurs in an artery supplying the brain, a heart attack (coronary thrombosis) if the artery supplies the heart itself, or a peripheral thrombosis in other parts of the body.

Probably the most important predictor of CVD is a high level of blood cholesterol: the more cholesterol in the blood, the higher the risk of dying from a heart attack.

Cholesterol and triglycerides are the two major lipids in the blood. Cholesterol is an essential structural component of all cell membranes, especially in the brain. It is used by the body to manufacture steroid hormones (including the sex hormones), anti-stress hormones (such as cortisol) and vitamin D, which regulates calcium levels in the body (essential for bone formation and cellular function). It is also used in the manufacturing of bile acids, which aid digestion. Approximately 90 percent of cholesterol is manufactured in the liver, while approximately 10 percent is obtained from the diet.

Triglycerides are produced by the esterification of glycerol with three fatty acid molecules. They are the body's major energy store, particularly in adipose tissue. When insulin levels become low during fasting, an enzyme called lipase helps to release the fatty acids for use as energy for the muscles and brain.

The body transports cholesterol and triglycerides through lipoproteins, which are particles of varying composition.

Swanton (1998:213) states that the different types of lipoprotein fall into three categories:

Low density lipoproteins (LDL) 
These transport cholesterol from the liver to the tissues. Approximately 70 percent of plasma cholesterol is in this form. Uptake of cholesterol by the tissues from LDL depends on the available number of LDL receptors on the liver and peripheral cells. LDL cholesterol is commonly known as "bad cholesterol", as this type of cholesterol may be deposited in the arteries and veins. High levels of LDL cholesterol are associated with coronary disease.

\section{High density lipoprotein (HDL)}

This lipoprotein transports excess cholesterol and phospholipids from the tissues back to the liver for excretion in bile, which is important for the disposal of cholesterol as the peripheral tissue is incapable of breaking down cholesterol. HDL is commonly known as "good cholesterol", as it may transport cholesterol away from the arteries to the liver for excretion. Increased levels of HDL are associated with a decrease in the risk for coronary heart disease. HDL levels tend to be raised in premenopausal women owing to the enhancing effect of oestrogen on HDL cholesterol. These levels fall during and after the menopause.

\section{Chylomicrons}

These are the largest of the lipoproteins, formed from dietary lipids in the mucosal lining in the intestine. The fatty acid compositions of the triglycerides reflect the fatty acids in the diet.

\section{Risk factors for CVD}

There are seven major risk factors for CVD. The greater the number of risk factors present in an individual, the greater the risk of CVD. The main risk factors are:

- Blood pressure $>140 / 90 \mathrm{mmHg}$

- Smoking

- Raised total cholesterol (>5,0 mmol/l)

- Age:

$>45$ years for males

$>55$ years for females

- Diabetes mellitus

- Family history of ischemic heart disease

- Premature menopause without hormonal replacement (female) (The Heart Foundation, 1999:2).

After assessing the patient and establishing the overall risk profile for CVD, the health provider should deter- mine whether the patient is at low, medium, high or very high risk for CVD. The different risk levels are described as follows:

\section{Low risk}

Men below 45, and women below 55 years of age with borderline hypertension (systolic 140 to $159 \mathrm{mmHg}$ and diastolic 90 to $99 \mathrm{mmHg}$ ) and no other risk factors, are considered to be at low risk. A tolerated cholesterol of $<6,2 \mathrm{mmol} / \mathrm{l}$ is allowed. (If the cholesterol reading is higher than $6,2 \mathrm{mmol} / \mathrm{l}$, it is an increased risk factor.)

\section{Medium risk}

Medium risk implies patients with borderline hypertension (systolic 140 to $159 \mathrm{mmHg}$ and diastolic 90 to 99 $\mathrm{mmHg}$ ) who have one or more risk factors. A tolerated cholesterol of $<5,2 \mathrm{mmol} / \mathrm{l}$ is allowed.

\section{High risk}

Patients with moderate hypertension (systolic 160 to $179 \mathrm{mmHg}$ and diastolic 100 to $109 \mathrm{mmHg}$ ) who have two or more risk factors, or patients with severe hypertension (systolic $>180 \mathrm{mmHg}$ and diastolic $>110$ $\mathrm{mmHg}$ ) without other risk factors are considered to be at high risk. A tolerated cholesterol of $<4,1 \mathrm{mmol} / \mathrm{l}$ is allowed.

\section{Very high risk}

Patients at very high risk are patients with severe hypertension (systolic $>180 \mathrm{mmHg}$ and diastolic $>110$ $\mathrm{mmHg}$ ) who have one or more risk factors, this group includes all patients with clinical cardiovascular disease or renal disease (German \& Hoffman-La Roche, 1996:31).

\section{DEFINITION OF TERMS}

The following terms need to be defined for purposes of clarity:

Primary health care (PHC): Primary health care is defined by the WHO (1978:15) as essential care made universally accessible to individuals and families within a community through their full participation and provided at a cost that the community and country can afford.

Primary care: Primary care is considered personal health care services that provide for first contact, 
continuous, comprehensive, and coordinated care. Care is directed primarily at an individual's pathophysiologic process (Stanhope \& Lancaster, 2000:43).

Managed health care: Managed health care is a system of health care delivery that influences the utilisation and cost of services, and measures performance. Selected providers are contracted according to specific standards to supply comprehensive health care. The goal is a system that delivers value by giving people access to quality, costeffective, health care (Ernst \& Young Management Services, 1993:86).

\section{PROBLEM STATEMENT}

As the above background information suggests, the problem statement of this research encompasses three areas of concern.

\section{Cost escalation}

In the last decade the main reasons for the cost explosion in the private sector have been related to new technology, rises in the cost of medicines and the age of the population.

\section{Medical scheme crisis}

Cost escalations coupled with poor management and inadequate supervisory controls have resulted in many medical schemes experiencing large financial losses.

As a result, there has been a decline in the number of medical schemes in South Africa from a total of 289 in 1980 to 244 in 1990.

\section{Managed health care has not reached its full potential}

The main reasons why there has been a delay in the introduction of true managed care principles which manage costs and health outcomes, are resistance by purchasers and providers, poor communication between schemes and doctors and the inability of schemes to introduce the necessary information and management systems (Ernst \& Young Management Services, 1993:31). The Medical Schemes Act 131 of 1998 (as amended) encourages and promotes innovative man- aged health care delivery.

\section{PURPOSE OF THE STUDY}

The purpose of the study was to examine the possible reduction of medical scheme claims for CVD through primary care, so that medical scheme benefits do not become exhausted so rapidly.

\section{Objectives of the study}

The objectives of the study were to:

- identify the risk factors that could provoke CVD;

- demonstrate the effect of nurse-based primary care on pending CVD;

- demonstrate the cost savings on possible complications emanating from risk factors that could proceed into secondary and tertiary levels of health care; and

- provide guidelines for the implementation of primary care interventions with regard to CVD

\section{ASSUMPTION}

The following assumption serves as point of departure for this study: The delivery of nurse-based primary care will increase primary (general practitioner) medical scheme claims in the short-term as a result of more comprehensive screening through early diagnosis and treatment (these conditions were previously undiagnosed and below the clinical horizon).

Through early detection and treatment of illnesses, secondary and tertairy claims will decrease inthe longterm.

\section{RESEARCH METHODOLOGY}

A quantitative approach was applied using a descriptive and exploratory design and three methods were utilised to elicit the necessary data.

\section{Population}

The population consisted of the main members of a selected medical aid scheme from a private company with its headquarters in Gauteng. The inclusive criteria for the participants of this research were:

- The participants had to be permanent employ- 
ees of the organisation.

- They had to be the main contributors to the medical scheme.

- Pensioners were excluded because the stress questionnaire (relating to job satisfaction) was not applicable to them.

\section{Sampling}

The sample was randomly selected from branches of this company in Pretoria, Stellenbosch, Port Elizabeth and Durban. Stratified random sampling was selected as a suitable method for this research.

Two-hundred-and-fifty questionnaires were distributed to all the principal members of the medical scheme in the four selected divisions. The 110 participants who returned the questionnaires made up the sample population for this study. A response rate of 44 percent was thus achieved.

\section{Instrumentation and data collection}

The three methods used for data collection were a questionnaire, clinical evaluations and case studies.

\section{Questionnaire}

The research instrument for conducting the survey was a questionnaire designed by the researcher in conjunction with the Cooper's Job Stress Questionnaire and Strategies for Mental Health, and the Lipid Research Clinic's Questionnaire, with the aim of determining:

- past and present health status;

- lifestyle;

- fitness activity;

- stress assessment; and

- clinical evaluation.

A self-administered questionnaire with fixed alternative options was distributed to the sample.

\section{Validity and reliability of the instrument}

Content validity was established by requesting a cardiologist and a physician (specialising in wellness) as well as the wellness team (consisting of the manager of the medical scheme, a general practitioner, a primary health nurse, two biokineticists, a dietician and a physiotherapist) of the company where the study was done, to evaluate the content.

To establish logical or sampling validity, items supported in the literature were included in the questionnaire and an expert on quality service research from the Department of Statistics of the University of South Africa (UNISA) was asked to evaluate the items used in the different sections.

Parahoo (1997:265) states that the reliability of a questionnaire refers to "... the consistency with which participants understand, and respond to, all the questions." The reliability of the questionnaire was tested by means of factor analysis and the Cronbach Alpha reading. Reliability coefficients generally range in value from a low of 0.00 to 1.00 , with higher values reflecting increased reliability (Polit \& Hungler, 1993:372).

Six factors were identified in the factor analysis namely, Recognition (Alpha $=0,9310)$, Attitude (Alpha = 0,7761 ), Relationships (Alpha $=0,7162$ ), Physical components (Alpha $=0,6864$ ), Mental components (Alpha $=0,8141$ ) and Behavioural components (Alpha $=$ 0,7008 ). Thus indicating that the questionnaire was reliable, with a high degree of internal consistency.

\section{Test-retest}

Reliability was also tested using a form of test-retest. The test-retest was conducted on six main members of the medical scheme who attended a particular primary health clinic of the organisation. All six members were informed about the purpose of the study and given the same covering letter used for the final sample. Their completion of the questionnaire was seen as consent. The clinical measurements (cholesterol, blood pressure, blood sugar, weight and height) were monitored.

The first set (pre-test) of questionnaires was distributed and filled in while the researcher remained at the clinic concerned, in case assistance was required. The second set (post-test) of questionnaires were distributed and filled in two weeks later by the same six participants. The questionnaires were labeled A and B. The results obtained with $A$ and $B$ were the same. The biological monitoring was repeated on the same participants. This was done to test the accuracy of the instruments used. The results were consistent. 


\section{Pilot study}

In this study, the test-retest, which was done for testing the reliability of the instrument, also served as the pilot study. Pilot subjects were chosen from the same population as subjects for the major study. A pilot study is a small-scale version, or trial run of the major study (Polit \& Hungler, 1993:62).

The pilot study revealed that the technical equipment (sphygmomanometers, Lipotrend $C$ instrument and Glucometer GX) were functioning properly and consistently. The pilot study indicated that the participants understood the questions in the questionnaire.

\section{Clinical evaluation}

The general health assessments included height and weight, blood pressure, total cholesterol and blood sugar evaluations as these variables are considered risk factors for CVD and could be measured physically.

Health days are a health promotion activity in this company. These health days include programmes for general health assessments, smoking cessation programmes, promotion of exercise and healthy nutrition and the promotion of the psychological well-being of the worker.

Health days were presented to the four selected departments during which professional nurses carried out the clinical evaluations according to strict procedures, using standardised and calibrated equipment.

\section{Case studies}

Case studies were used to illustrate the cost savings that could be obtained by the delivery of managed primary care for cardiovascular conditions. Three case studies were done to compare the primary, secondary and tertiary costs of CVD health care costs.

The researcher examined the individual's health status in-depth, by probing into the history to ascertain the development of the cases' cardiovascular conditions. The researcher attempted to thoroughly analyse and understand the variables that influenced the costs of health care for these particular cases.
The Statistical Package for Social Science (SSPS) was used to analyse the data.

\section{Ethical considerations}

Three forms of informed consent was achieved by firstly obtaining permission from the manager of the medical scheme, thereafter explaining the purpose of the research to the members of the medical scheme and indicating that their participation would be voluntary, and thirdly obtaining written permission from the participants involved in the case studies.

Anonymity was ensured by requesting participants to refrain from providing any identifying information on the questionnaires, and confidentiality was confirmed with the participants in person and in writing, care was taken not to reveal the participants' identity during reporting on, or publication of the findings.

\section{RESULTS}

The most important results are provided in terms of:

- Age and gender

- Past and present health status

- Lifestyle

- Stress and mental health

- Clinical assessment.

\section{Gender and age risk profile}

Of the men older than 45 years of age, 51,2 percent $(n=25)$ were categorised as high risk candidates, while only 8,8 percent $(n=5)$ of the females older than 55 years fell into the high risk group

These findings regarding gender and age are in accordance with Smeltzer and Bare's (2000:537) statement that the incidence of CVD is significantly lower in females below the age of 55 than in males owing to estrogen which affects the cholesterol levels, reducing low-density lipoprotein levels, raising high-density lipoprotein levels, and improving blood flow.

\section{Past and present health status}

- Seventy-three percent $(n=80)$ of the participants had no known past and/or present health risk factors associated with CVD, while 
- twenty-seven percent $(n=30)$ of the participants had current and/or a history of cardiovascular related conditions.

\section{Lifestyle}

\section{- Smoking habit}

Thirty-seven percent $(n=19)$ of the males and nineteen percent $(n=11)$ of the females were smokers or ex-smokers and were identified in this study by means of their medical profile to be at a high risk for CVD. This is in accordance with Smeltzer and Bare's (2000:597) statement that smoking increases the development of CVD and the likelihood of thrombus formation.

\section{- Exercise}

The Lipid Research Clinic's Questionnaire indicated that 41,8 percent $(n=46)$ of the participants exercised regularly. Fifty eight percent $(n=64)$ were non-active participants. As the LDL of non-active people is usually high, 58,2 percent of the participants thus have an increased risk for CVD.

- Diet

Fourty six percent $(n=50)$ of the participants followed a healthy, balanced diet, and 54 percent $(n=60)$ followed "unhealthy" eating habits. Badly managed diets have been linked to heart diseases, obesity and other illnesses.

\section{Stress}

The Coopers Job Stress Questionnaire indicated that the participants experienced the following job stress levels:

- Sixty-four percent $(n=69)$ of the participants reflected a low job stress profile.

- Thirty-six percent $(n=40)$ reflected a medium job stress profile.

- No participants reflected a high job stress profile.

The Strategies for Mental Health indicated that the participants experienced the following mental stress levels:

- Eighty-nine percent $(n=98)$ of the participants reflected a good mental health profile.

- Ten percent $(n=11)$ reflected an average mental health profile.

- One participant $(0.9 \%)$ reflected an unhealthy mental health profile.

According to these results, the majority of the job and mental stress levels of the participants were not a risk factor for CVD. There was only one participant with high stress levels, who consequently had an increased risk for CVD.

\section{Clinical details}

The following health assessments were done:

\section{- Height and weight}

The BMI (Body mass index) of the participants was reflected as follows: Fourteen percent $(n=14)$ exceeded the optimal weight for the avoidance of CVD and the prolongation of life. It is encouraging that 75 percent $(n=76)$ had a normal percentage of body fat. There were 12 participants $(11 \%)$ who were underweight.

\section{- Blood pressure}

Sixty-eight percent of the participants $(n=74)$ presented with normal blood pressure levels, while 25 percent $(n=28)$ presented with borderline blood pressure levels. There were eight participants $(7 \%)$ who presented with high blood pressure levels and thus had an increased risk of CVD.

\section{- Cholesterol}

Cholesterol should be seen as a major risk factor for heart disease. Seventy-seven percent $(n=79)$ of the participants presented with cholesterol levels above the recommended value of $<5,0 \mathrm{mmol} / \mathrm{l}$ (Boehringer, 1998:124) while 22,5 percent $(n=23)$ of the participants had normal cholesterol values. These findings are in accordance with Fox's (1999:7) view that South Africa has the highest prevalence of hypercholesterolemia in the world.

\section{- Blood sugar}

Twenty-seven percent $(n=30)$ of the participants presented with low blood sugar values 
while 70,9 percent $(n=78)$ presented with normal blood sugar levels. There were two participants $(1,8 \%)$ with blood sugar levels above the recommended value of 4,4 to 8,00 (nonfasting) (Boehringer, 1998:54) and who thus had an increased risk of CVD.

\section{Results from the case studies}

To demonstrate the costs involved in primary, secondary and tertiary treatment of risk factors for CVD, case studies were carried out to serve as examples. The histories of all three cases were scrutinised. Unfortunately, the clients did not record all the medical costs incurred during the preceding years, however, the costs over one year (1999 - 2000) could be obtained and were interpreted for all three case studies.

When risk factors for CVD are diagnosed and treated early, there are definite financial advantages, as can be seen from the figures in Table 1.

In this study, 32,15 percent of participants presented with high risks and 15,2 percent with moderate risks for CVD. Given that many of these participants may develop CVD, and will possibly need tertiary treatment for CVD, the cost benefit of timely primary care interventions quickly exceeds the financial loss attached to unmonitored cardiovascular risks, which is beneficial to both the client and the medical scheme.

\section{CONCLUSIONS}

The conclusions are based on the objectives of the study.

\section{Objective 1: Identify the risk factors that could provoke CVD}

In general, managed primary care was successful in terms of early identification and evaluation of risk factors that could provoke CVD conditions. Out of the 110 participants, who required primary care interventions, there were 35 participants with a high risk, and 17 with a medium risk for CVD.

\section{Objective 2: Demonstrate the effect of nurse-based primary care on pending CVD}

The results demonstrated that a targeted approach should be followed where interventions are focused to improve the health status and functioning of individuals who were at the highest risk for CVD.

The effect of nurse-based primary care was demonstrated through the monitoring of blood pressure, cholesterol and blood sugar, and early treatment and detection of complications. During these sessions the primary health care nurse motivated and encouraged the participants with high risk factors, to understand and attempt to control their medical condition through education and regular updated information. Emphasis was also placed on striving towards living a healthy lifestyle.

Table 1: Costs of medical treatment (including medication, pathology and radiology) for patients with risk factors for CVD

\begin{tabular}{|l|l|l|}
\hline \multicolumn{1}{|c|}{ Case study } & \multicolumn{1}{|c|}{ Level of intervention } & \multicolumn{1}{|c|}{$\begin{array}{c}\text { Total cost for } \\
\text { one year }\end{array}$} \\
\hline $\begin{array}{l}\text { Case study 1: Risk factors for CVD } \\
\text { (hypercholesterolemia) }\end{array}$ & Primary care costs & $\mathrm{R} \mathrm{7} \mathrm{895.49}$ \\
\hline $\begin{array}{l}\text { Case study 2: Risk factors for CVD (soft } \\
\text { plaque accumulation) }\end{array}$ & $\begin{array}{l}\text { Secondary treatment } \\
\text { (Chelation treatment) }\end{array}$ & $\mathrm{R} 24738.85$ \\
\hline $\begin{array}{l}\text { Case study 3: Risk factors for CVD (coronary } \\
\text { occlusion) }\end{array}$ & $\begin{array}{l}\text { Tertiary treatment } \\
\text { (Bypass operation) }\end{array}$ & $\mathrm{R} 203775.15$ \\
\hline
\end{tabular}


Objective 3: Demonstrate the cost savings on possible complications emanating from risk factors that could proceed into secondary and tertiary levels of health care

It is important to note that the economic impact of disease prevention interventions can only be seen in the medium- to longer-term. However, if cardiovascular related diseases could be diagnosed and treated early, the financial benefits could be substantial. This is illustrated by the comparison of primary, secondary and tertiary level treatment costs as they related to the three case studies summarised in Table 1.

\section{RECOMMENDATIONS AND THEIR IMPLICATIONS FOR NURSING}

The following recommendations are made on the basis of the results and conclusions of this research, the recommendations are threefold:

\section{Recommendations regarding nurse- based primary care for CVD}

Nurse-based primary care should focus on the prevention of CVD at the primary and secondary levels, and should be based on the following specific actions:

\section{Primary prevention}

The following primary care is recommended in this study: The 36 hypertension and 79 high cholesterol candidates must receive health awareness and behavioural change interventions such as:

- $\quad$ taking responsibility for oneself;

- weight management;

- $\quad$ sufficient exercise;

- control smoking;

- $\quad$ stress management; and

- follow-up primary prevention programme (consists of monthly evaluations to monitor the progress being made).

\section{Secondary prevention}

At a secondary prevention level, the professional nurse can play an important role with regard to the early detection of cardiovascular disease through the following measures:
- Annual periodic medicals conducted by a primary health care nurse for those employees who do not require compulsory work-related medical examinations.

- A focused approach whereby specific screening protocols should be developed by the primary health care nurse for certain priority groups such as postmenopausal women.

\section{Recommendations regarding cost- effective management of the medical scheme}

The main focus of the medical scheme under investigation needs to be on primary care, which is essentially prevention-oriented.

\section{Periodical medical screening}

The additional resources required to conduct periodical medical screening of staff members would be minimal. It is recommended that these medicals should be phased in over the period of a year.

\section{Quality health benefits}

The company under investigation aims to secure quality health benefits at reasonable rates for its employees. The benefits of individuals often become exhausted prematurely thus various mechanisms have been introduced in conjunction with the medical scheme to contain escalating health care costs. These include benefit reductions, co-payments at the point of service, communication and interaction with providers, and advising individuals with regard to responsible utilisation of medical services.

\section{Recommended self-care program}

The following mechanisms could be introduced by the $\mathrm{PHC}$ nurse in conjunction with the medical scheme to improve the self-care ability of members:

\section{Self-care reference guide}

The current medical team of the company (consisting of the general practitioner, the primary health care nurse, the psychologist, the dietician and two biokineticists) could collaborate with the medical scheme to compose a self-care reference guide that can serve as a source of information which will allow the member to make an informed decision about his or 
her family's health.

\section{Medical help-line facility}

A 24-hour medical help-line facility provides the necessary support and guidance to the members and may act as a backup or alternative to the self-care guide.

\section{Member communication to support self- care and general wellness}

Member communication (through newsletters, information sessions and e-mails), between the medical scheme, PHC clinic and employees, with respect to self-care reinforces the self-care guide and at the same time allows the readers to become better informed about their health.

\section{Self-care support programme for high cost/chronic members}

It is a commonly known fact that a large proportion of the medical scheme's costs can normally be attributed to a small percentage of the members. Active support of these members by the PHC nurse by means of telephonic counseling and by providing educational material directly to their home address, on the management of their particular conditions, has proved to be very successful in containing health care costs.

\section{CONCLUDING REMARKS}

The above study was implemented to establish whether the application of nurse-based primary care interventions could be successful in effecting health care savings. The overall outcome shows that savings can be made as a result of nurse-based primary care and that the results are worth the effort, as a third of the participants were identified as having a high risk for CVD. Nurse-based primary care can make it possible to contain costs and to keep the medical scheme viable and within reach of the employees.

Nurse-based managed primary care is here to stay in South Africa. This encourages people to achieve as high a level of wellness as possible so that they can live maximally healthy lives and avoid preventable illnesses. It has become a cornerstone in health policy because of the need to control costs and reduce unnecessary sickness and death.

\section{LIST OF REFERENCES}

BOEHRINGER, M 1998: Lipotrend C. Instruction manual. Germany: Rotkreuz.

CESLOWITZ, SB 1993: Managed care: controlling costs and changing practice. Medsurg Nursing: Official Journal of the Academy of Medical-Surgical Nurses, 2(5):359-366.

DENNILL, L; KING, LJ \& SWANEPOEL, T 1999: Aspects of primary health care. Community health care in Southern Africa; second edition. Pretoria: International Thomson.

ERNST \& YOUNG MANAGEMENT SERVICES 1993: Introduction to managed health care in South Africa. Medical Association of South Africa, 1(1):16-86.

FOX, KA 1999: Modern concepts of atherosclerosis prevention. South African Medical Journal, 10(6):6-10.

GERMAN, I \& HOFFMAN-LA ROCHE, B 1996: Cardiovascular diseases and the role of antioxidant vitamins. Health and Hygiene, 7(1):27-31.

GORE, A 1993: The search for successful health insurance principles in a changing South African health care environment. Transactions of the Actuarial Society of South Africa, 9(3):18-67. HEART FOUNDATION OF SOUTH AFRICA 1999: Cholesterol education program. Roggebaai: Heart Foundation.

KONGSTVEDT, PIR 1993: The managed health care handbook. Maryland: Aspen.

KREIDER, S 1999: University of Texas-Houston Health Science Center. Primary Health Care, 5(1):65.

PARAHOO, K 1997: Nursing research principles, process and issues. London: Macmillan.

POLIT, DF \& HUNGLER, BP 1993: Nursing research principles and methods. Philadelphia: Lippincott.

SMELTZER, SC \& BARE, BG 2000: Medical-surgical nursing. Philadelphia: Lippincott.

STANHOPE, M \& LANCASTER, J 2000: Community and public health nursing; fifth edition. St Louis: CV Mosby.

SOUTH AFRICA (REPUBLIC) 1967: Medical Schemes Act 72 of 1967. Pretoria: Government Printers.

SOUTH AFRICA (REPUBLIC) 1998: Medical Schemes Act 131 of 1998 (as amended). Pretoria: Government Printers.

SWANTON, RH 1998: Cardiology. St Louis: CV Mosby.

VAN EMMENIS, G 2000: Personal interview. 4 April 2000. Pretoria. WORLD HEALTH ORGANIZATION. 1978: Primary health care: Report of international conference on primary health care. Alma-Ata. Geneva: WHO.

WORLD HEALTH ORGANIZATION. 1988. From Alma-Ata to the year 2000: Reflections at midpoint. Geneva: WHO.

WORLD HEALTH ORGANIZATION. 1998: The World Health Report. Geneva: WHO. 